\title{
ПЕРЕОСМЫСЛЕНИЕ БУДУЩЕГО ВОДЫ НА НАШЕЙ ПЛАНЕТЕ
}

\section{ОБ3ОР СТАТЬИ}

DIAS, Deusira Nunes Di Lauro ${ }^{1}$

DIAS, Adailton Di Lauro ${ }^{2}$

DIAS, Deusira Nunes Di Lauro. DIAS, Adailton Di Lauro. Переосмысление будущего воды на нашей планете. Revista Científica Multidisciplinar Núcleo do Conhecimento. 04 год, Эд. 08, Vol. 06, стр. 19-32. Август 2019 года. ISSN: 24480959

\section{PEЗЮME}

Считается наиболее важной, драгоценной и незаменимой жидкостью для выживания человеческой жизни на Земле, вода была причиной постоянной озабоченности, потому что способ, которым общество присвоило и использовал водные ресурсы на планете Приверженность качеству, а также доступ у многих общин к этому жизненно важному ресурсу для поддержания жизни. Эта работа направлена на анализ и обсуждение стратегий, которые обеспечивают сохранение и устойчивое использование воды на планете, решение, что в некоторых регионах Бразилии и мира, уже с крайней нехваткой воды и, по мнению некоторых авторов, эта проблема как правило, эскалации все более и

\footnotetext{
${ }^{1}$ Окончил в ходе письма в Государственном университете Баии - UNEB - Кампус X; Пост окончил на португальском языке в Университете Вале-ду-Крикаре и регулярный студент магистра образования в Университете Internacional Unigrendal онлайн.

2 Окончил по письмам Унеб, окончил на английском языке Unimes, после окончания комплексных колледжей Jacarepagu (FIG), и регулярный студент магистра в области образования в Международном университете Unigrendal онлайн.
} 
более из-за нескольких фракторов, и основные из них являются быстрый рост населения и большой спрос на продовольствие в мире. Законы, регулирующие водные ресурсы, все чаще корректируются в целях сохранения водных ресурсов и всей окружающей среды. Бразилия показала, что необходимо сохранить, однако многое еще предстоит сделать для сведения к минимуму воздействия, причиняемого человеком окружающей среде.

Ключевые слова: вода, дефицит, сохранение, устойчивость.

\section{ВВЕДЕНИЕ}

Человечество достигло, особенно в этом столетии, бесчисленных достижений, которые никогда не представляли себе наука и техника. Тем не менее, проблема воды и поддержания жизни на планете приняла большую часть населения мира задуматься, что делать, чтобы каждый человек имеет доступ к воде, но это не всегда есть ответ, потому что человек не всегда или почти никогда не будет D C учетом необходимости сохранения этого очень ценного товара.

Эта озабоченность в будущем не происходит случайно, в конце концов, данные о распределении, резерве и наличии воды на планете свидетельствуют о необходимости искать альтернативы для сохранения, как говорит VICTORINO:

Известно, что почти вся поверхность планеты Земля покрыта водой: из океанов, рек и озер, ручьев и сангхов. Вода из полярных ледяных шапок, дождевая вода, много, много воды... Но на самом деле не все голубое (цвет, который покрывает землю - из-за воды, когда она видна из космоса), потому что вся вода на планете (1,37 млрд км 3) состоит в основном из двух типов: соленая вода морей и пресная вода рек, озер и недр. Однако 97\% от общего количества занято соленой водой, непригодной для потребления. С так называемым «водным циклом» (процесс испарения и возвращения воды на поверхность в виде дождя, снега, града или мороза) вода перекомпонируется несколькими способами, давая жизнь 
растениям и генерируя несколько биомммов после естественного течения жизни. Природа мудра и просто потому, что, когда вода выходит в атмосфреру в виде испарения, пот компенсируется осадками. Эта разница между объемом воды, которая падает, и объемом воды, которая испаряется, составляет около 45000 кубических километров в год, которые, в теории, человек может потратить. Только $20 \%$ от этого общего объема доступно. Пригоденная вода находится в реках, озерах, дождевой воде и подземных водах. Однако все они в совокупности соответствуют лишь 1\% объема пресной воды (VICTORINO, 2007, стр. 16).

Рисунок 1-график-"распределение воды на Земле"

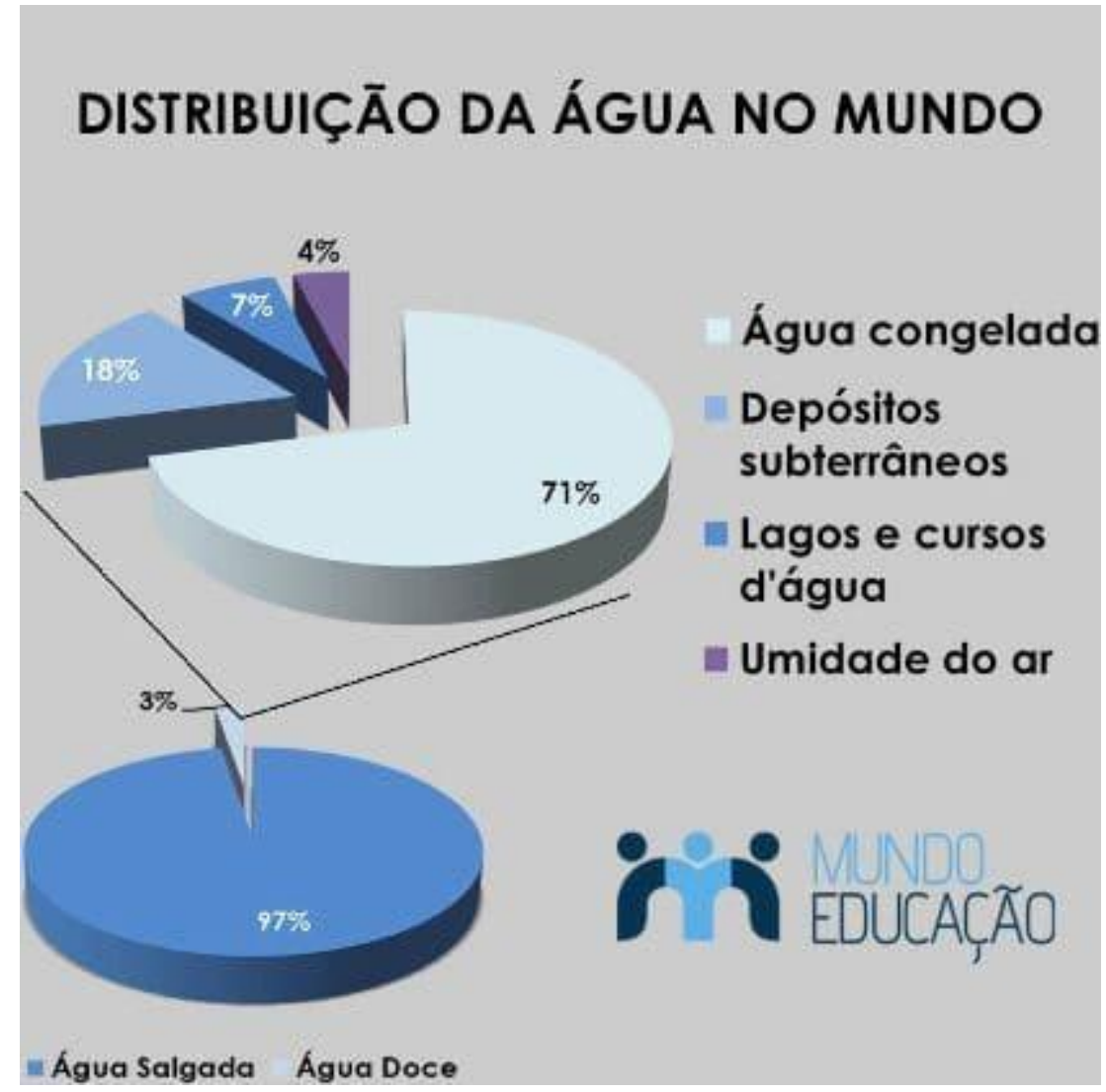

(Источник: Всемирный образовательный сайт)

При анализе графика выше, отмечается, что количество воды, доступной для использования является недостаточным, так как: 
Если мы соберем 1,5 литра воды, как мы находим его на планете, и разделить его пропорционально, количество пресной воды, доступные будет эквивалентно одной незначительной капли. И что еще более сложно, этот небольшой остаток все больше и больше загрязнен, особенно в крупных городах, из-за увеличения населения мира, что только в прошлом веке стало в три раза больше, что вызвало увеличение заводов, больше отходов и больше орошения В посевных культурах. По данным Всемирного банка, сегодня около 80 стран сталкиваются с проблемами с поставками. Наиболее критическая ситуация сложилась в Азии, где 60\% населения проживает лишь на 32\% имеющейся пресной воды (VICTORINO, p. 17).

При анализе всех этих данных можно оценить тяжесть воздействия, вызванного действиями человека на окружающую среду и, в частности, на воду, которая считается жизненно важным ресурсом для жизни на Земле. Многие страны уже приняли положения в области сдерживания и сохранения на основе договоров, соглашений, с тем чтобы свести к минимуму такие последствия. Однако значительная часть населения мира по-прежнему игнорирует, что будущее находится под угрозой и что произойдет изменение не только менталитета, но и отношения к использованию этого ресурса, который был использован безответственным образом долгая история.

Известно, что население мира растет беспорядочно, и это также требует значительного увеличения промышленного сельскохозяйственного производства в попытке гарантировать продовольствие для всех, что оказывает все более сильное давление на окружающую среду. В связи с этим необходимо найти стратегии, которые отменяют последствия, так как население более восьми миллиардов человек ожидается в 2020 году:65\% в прибрежных районах и $60 \%$ в городах с населением более 2,5 миллиона человек. Кроме того, за короткий период времени использование водоснабжения значительно возросло: хотя в период ремонта не изменился уровень водных ресурсов, с 1900 по 1995 
год в ходе встречного отъезда объем использованного индекс прироста населения) и в два раза больше с 1975 года. Из общего объема потребляемой воды на планете сельское хозяйство поглощает в среднем $70 \%$ запасов воды в мире, а в слаборазвитых странах этот показатель еще выше, регистрируя увеличение на 80-90\%, в среднем на 20\% для промышленности и 10\% для внутреннего использования и ОР Трос.

При анализе положения Бразилии в этом контексте становится еще более очевидным, что вода не используется рационально, что ставит под угрозу и значительное предложение и качество жизни во многих регионах страны.

\section{ПОТРЕБЛЕНИЕ ВОДЫ В СТРАНЕ}

Рисунок 2-график - потребление воды в стране

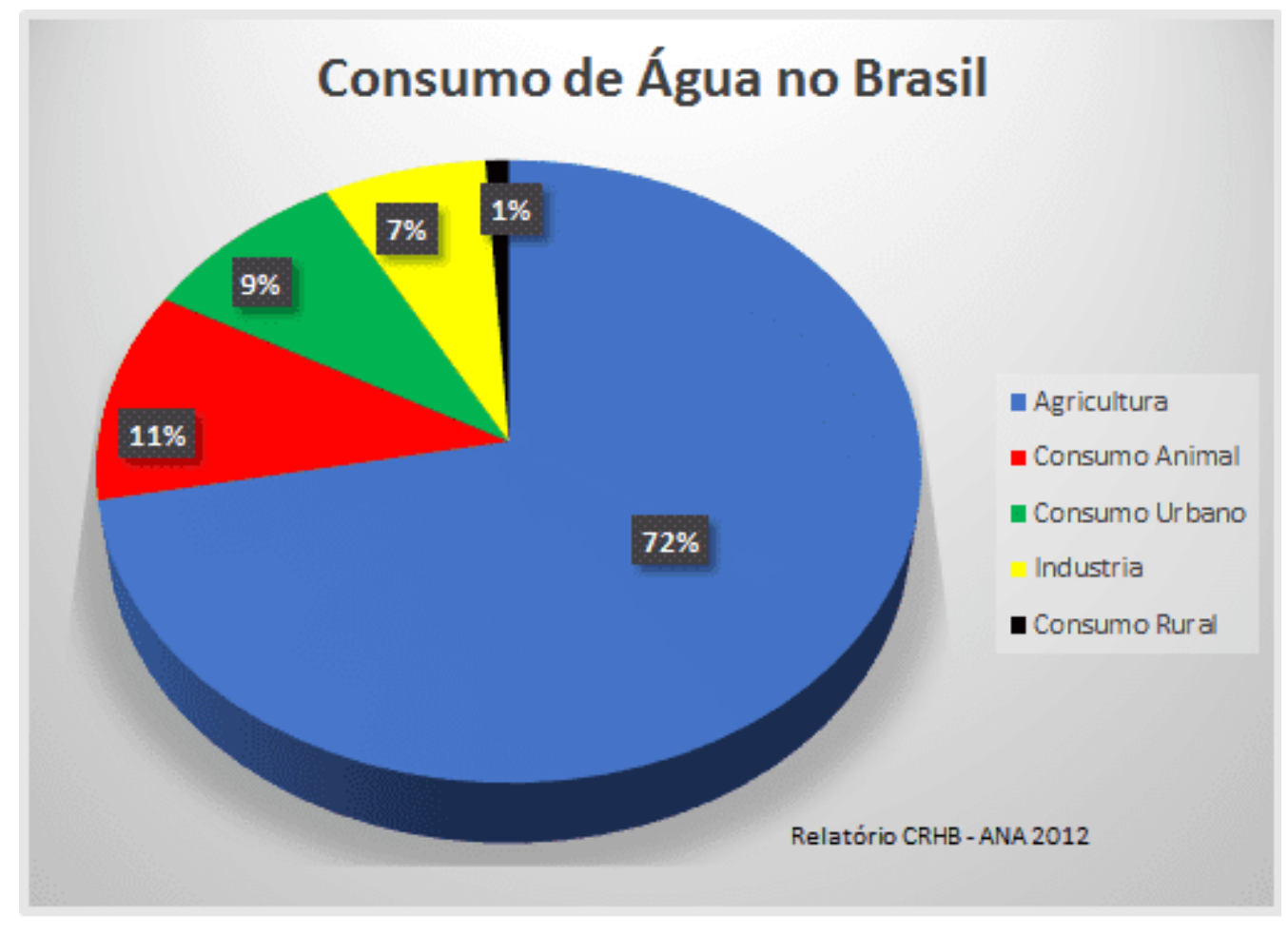

(Источник: EOS Консультанты)

Диаграмма выше указывает на сельское хозяйство, как большой злодей в потреблении и отходов воды в Бразилии, и, хотя страна является пионером в 
утверждении законов, которые ограничивают потребление и налагает некоторые санкции на тех, кто совершает злоупотребления в потреблении и использовании воды Известно также, что не хватает надзора со стороны правителей для обеспечения соблюдения законов, то есть, хотя есть законы сохранения, на практике еще далеко не так.

В настоящее время, несмотря на правовую концепцию общего пользования людей, вода является ресурсом для многих, экономической ценности. Это обусловлено растущим спросом на воду для различных видов использования, что сопровождает городское и промышленное развитие стран. В настоящее время большие проблемы, связанные с водой, возникают не из-за природы, а возникают из-за неправильного использования отходов и импровизации, а также широко распространенного загрязнения окружающей среды.

Водный кодекс, закон больше, чем дисциплина использования воды в Бразилии 10 июля 1934 года, уже определенный возраст, но не так это уже не ток, потому что он классифицирует правовые категории, дискриминирует использование воды и ее заповедей и , прежде всего: стремится обеспечить общие интересы общества. В старом коде можно было найти частный домен воды в некоторых случаях, но это было extinguaged с октября 1988 года, когда все тела D и воды стали общественным достоянием.

\section{КАЧЕСТВО ВОДЫ, ПОТРЕБЛЯЕМОЙ МЫ}

Качество воды, доступной на планете, является еще одним аспектом, который также вызывает озабоченность со стороны учреждений здравоохранения во всем мире, поскольку болезней можно избежать при использовании обеззараженной воды. Качество воды решил о своей удаче некоторых регионов мира в экономическом характере, в основном в связи с производством пива. Но не только в отрасли пивоваренных заводов важна чистота воды, она также необходима в отраслях гобеленов, в кожевенном цехе, в тканевой промышленности и в драгоценных камнях. Кроме того, качество воды будет определять качество жизни ее потребителей. Когда нет надлежащей питьевой 
воды для потребления человеком, в результате высокий уровень заболеваний и других проблем, связанных с ними. Это беспокойство, которое в прошлом определяли успех или неудачу наиболее развитых стран, как говорит Селия Джурема:

Человек всегда заботился о воде. В течение 4000 лет до н.э., первые законы, которые были известны были кодексы, которые регулируют использование воды, написанные шумерами. Но не все цивилизации были осторожны в этом. Записи показывают, что майя были вынуждены покинуть город Тикал, расположенный в полном тропическом лесу, где были найдены руины пирамиды Солнца, потому что они не знали, как правильно хранить воду, кроме производства растущих эрозий и больших Дефорти, потому что они использовали древесину даже во внутренних структурах колонн своих гигантских храмов. В Мексике, на полуострове Yucatan, бог дождя, Chac, был revered и, когда вода была вешена, новые виски были раскрыты в уповании что бог воды спасет Мауа от засух. Они часто встречаются, мотивы бога дождя майя у основания пирамид. Сосуществование с реками принесло мудрость населению на протяжении всего развития человечества, фараоны, планировали свои города, покидая приправы свободных "(VICTORINO, 2007, стр. 19).

C более отдаленных времен, вода всегда была одним из наиболее важных социальных регуляторов. Вокруг воды были организованы структуры крестьянских обществ и сельских общин, где условия жизни тесно связаны с почвой. Были редкие случаи, когда все члены общины находились на одном уровне по отношению к воде - доступ к ней почти всегда был связан с неравенством. Это заставляет нас понять, как это отношения человека с водой и друг с другом из-за воды. Человек, однако, потребовалось много времени, чтобы заботиться и заботиться эфффективно о качестве воды - многие до сих пор не понимают, что, больше дней меньше день, дефицит будет реальностью, и 
продолжать использовать воду indiscriminally для упрощения задач Es, как мыть машину с шлангом или подметать тротуар с струями D воды. Другие до сих пор играют все виды отходов в озерах, реках и ручьях. Как долго общество будет продолжать действовать столь несущественно и безответственно? Вода, этот минерал, который мы оба знаем и который является частью нас, существует по крайней мере 3,9 миллиарда лет. «Рациональное существо» за несколько поколений уже успело пойти на компромисс не только по качеству, но и по количеству этой естественной весны. Можно оценить степень развития населения по качеству водоснабжения и санитарии, которые предоставляются населению. Способность поддерживать человеческую жизнь и общество является сложной, динамичной и варьируется в зависимости от того, как человек управляет экологическими ресурсами. Странно, что мудрые священники древности не воспринимали существующую корреляцию между водоснабжением и сохранением лесов. В то время, посадка была привилегией только князей, это было не через их ' блестящие ' головы, которые потребуют фронтов плантаторов для лесовосстановления бредили земли:

8000 лет назад в Бразилии было 9,8\% мировых лесов. В начале 21го века этот показатель снизился до 28\%, а, что еще хуже, 64 млн кв. км существующих лесов до демографического и технологического роста людей остаются менее 15,5 млн, что примерно на 24\% превышает 24\%. Это означает, что более $75 \%$ мировых лесов уже исчезли... Еbc

Восстановление деградированных природных ресурсов затруднено, чем их сохранение; И, многие из них, как вода, не могут быть восстановлены, когда она заканчивается нет пути назад, когда она заканчивается навсегда. Ложная иллюзия о том, что вода никогда не закончится очевидной в природе, возможно, отчасти оправдывает историческое пренебрежение людей в их отношениях с водными ресурсами. Известно, что питьевой воды доступно не столько, сколько пейзаж заставляет нас видеть. То, что мы на самом деле имеем в качестве питьевой воды, составляет всего 0,03\% от общей воды на планете. Это 
незначительное количество должно получить все возможные помощи, однако, это не то, что мы видим почти на каждом континенте, в конце концов, основные водоносные горизонты в настоящее время исчерпаны с более высокой скоростью, чем их естественная способность к восстановлению.

\section{НЕИЗБИРАТЕЛЬНОЕ ИСПОЛЬЗОВАНИЕ ВОДЫ И ПРИВЕРЖЕННОСТЬ КАЧЕСТВУ ЖИЗНИ ЧЕЛОВЕЧЕСТВА}

Не стоит заходить слишком далеко, чтобы воспринимать ситуации расточительства и девальвации природных ресурсов. С водой все то же самое, и в теории идея сохранения этого ресурса, несмотря на несколько подчеркнул, на практике не существует большой мобилизации для предотвращения предсказуемых последствий будущего с нехваткой воды. Следующая цитата четко определяет ситуацию, о которой идет речь:

Одна из главных задач общества в XXI веке связана с насущной необходимостью сохранения водных ресурсов в качественном и количественном, при сценарии увеличения численности населения и низкой устойчивости производственных процессов и потребления.

[...]Эти прогнозы роста населения и оценки, связанные с производством продовольствия, сохранением и распределением, учитывают, что если население мира достигнет 10 миллиардов жителей в ближайшие 50 лет, то у нас будет 70\% жителей планеты Устранение недостатков в водоснабжении, затрагивающих около 1,06 миллиарда человек, которые не будут иметь даже воды для основных продуктов питания (SILVA, 2009, стр. 1).

Хотя во многих странах мира вода уже превратилась в спор, порождающий различные конфликты, Бразилия еще не осознала той большой ответственности за качество жизни будущих поколений. По словам Селии Jurema Айто, Бразилия является привилегировой страной с точки зрения наличия воды, как он рассчитывает с 28\% южноамериканских запасов и 12\% мировых запасов воды. 
На территории Бразилии 72\% воды находится в бассейне Амазонки. Река Амазонка имеет 6885 километров расширения и является крупнейшим в мире по объему воды, сбрасывая 175 миллионов литров в секунду в Атлантическом океане. Однако нельзя забывать о том, что рост населения также приводит к тому, что к нам может доходить и риск дефицита. По словам Селии Хуремы, в период с 1970 по 2000 год в Бразилии численность городского населения составила от 55\% до $82 \%$ от общей численности населения. Известно, что более 1,4 миллиарда человек не имеют доступа к питьевой воде, а еще 2 миллиарда человек не имеют элементарных санитарных условий.

По мере того как самомоднейшее человек эволюционировало в технологию, он перестал иметь контакт с его естественной сущностью, пошел дальше жить всегда более далеко от его основания, природы, и стать тревожным и раздражающим существованием. Коллективный дисбаланс, с которым сталкивается наша планета, представляет собой дисбаланс людей, которые составляют население мира. Этот дисбаланс связан с провалом в процессе эволюции человека, который дистанцироваться от своего происхождения, стремится, в большинстве случаев, его индивидуальное благосостояние, забывая, что мы являемся частью живого организма называется "общество" и для него Эффрективно развивайся, необходимо обеспечить благо всех, а не только себя. В крупных городах, считается, что все больше и больше людей чувствуют себя одинокими, беспомощными, даже живущих среди толпы, что делает их более индивидуалистическими и эгоистичными с каждым днем. И хотя в настоящее время, есть идея сохранения, по крайней мере в рекламе многих компаний, которые стремятся поднять фрлаг сохранения "бизнес-маркетинг", что выгодно, великая правда в том, что мало что делать для сохранения окружающей среды и Следовательно, вода в стране. Поэтому мы ощущаем неэффективность, несмотря на столь клоя усилий наших правителей, неправительственных организаций и даже самого населения в связи с экологическим вопросом, поскольку вся работа проводится в основном для решения проблем Когда процесс изменения и совершенствования должен начинаться на внутреннем уровне каждого человека. 
К сожалению, население мира, занимающей все больше и больше места на планете, несет прямую ответственность за деградацию рек, прибрежных районов, океанов, пляжей, и, поскольку это население не растет, объем мусора с каждым днем становится все больше. Чтобы получить представление о проблеме, только американцы производят 212 миллионов тонн мусора в год и перемещаются почти 3 миллиона пластиковых бутылок в час. Он принимает совесть, чтобы избавиться от такого рода мусора в местах для переработки. В Бразилии национальная политика в области твердых отходов (Федеральный закон 12.305/2010) определяет, что все материалы, производимые отечественной и коммерческой деятельностью, которые можно будет собирать государственными службами по очистке, должны быть направлены в пункт назначения Конец только тогда, когда это не возможно повторноиспользовать его, либо путем переработки, повторного использования, компостирования или выработки электроэнергии. Там, где нет жизнеспособной технологии, отходы должны предназначаться для свалок. Однако из объема, произведенного в 2016 году, почти 30 миллионов тонн не имели соответствующего назначения, что составляет процент 41,6\% от общего объема производства, что превращает твердые отходы в серьезную экологическую проблему, поскольку неадекватное удаление может Загрузка этого материала в ручьи и реки и, следовательно, достигает океанов, в дополнение к проблеме свалок, воздействие на здоровье населения и других негативных последствий.

В среднем производится 80 миллионов тонн твердых бытовых отходов, что составляет почти 470 кг на одного жителя, при этом 60\% от этого объема составляет перерабатываемый материал. Однако только 3\% производимого мусора направляется на переработку.

Создается впечатление, что везде поверхностные воды загрязняются пугающим разнообразием городских, промышленных и сельскохозяйственных отходов. Даже в промышленно развитых странах, где действует законодательство о качестве воды, загрязнение по-прежнему является проблемой, которая беспокоит. В Соединенных Штатах было установлено, что 60\% обследованных 
озер загрязнены питательными веществами из удобрений и навоза животных, что приводит к почти массовой гибели рыбы, в дополнение к ухудшению качества воды. В Канаде 20000 озер пострадали от кислых дождей.

Демографический и экономический рост Бразилии в последние годы привел к использованию водных ресурсов, намного превышающую ее возможности для поддержки как количества, так и качества. Серьезные проблемы в области управления водными ресурсами вызваны беспорядочным расширением городского населения и ограниченным наличием водных ресурсов, кроме того, государственная политика, направленная на сохранение водных ресурсов, недостаточна перед лицом Спрос на потребление и использование. Оккупация плоских пространств, вблизи рек и без контроля, вызвало в течение многих лет, небольшие наводнения в большом количестве городов на юге и юго-востоке, в Бразилии. В 80-е годы произошло несколько наводнений на берегу реки, которые имели большие потери, главным образом в Паране, Санта-Катарине, Сан-Паулу и Минас-Герайсе. В нашей стране существует большое разнообразие ситуаций, с большим количеством водных ресурсов в северных и средних районах и дефицит омнивает в северо-восточных и юго-восточных регионах, в оппозиции к большей концентрации спроса, наряду с южным регионом. Городское развитие также увеличивает водостойкие и низкоабсорбционные зоны через жилые дома, прогулки, улицы, автостоянки и даже парки. Поскольку дождевая вода не может проникать в почву, дополнительный объем стекает в дренажную систему в направлении рек. В течение 70-го десятилетия существовала большая надежда на то, что можно было спланировать рост городов и спланировать их будущее гармонично. Однако 37 лет спустя, как представляется, городское планирование в Бразилии или даже за рубежом было атрофировано, что привело к накоплению проблем.

Бразильская набережная является жертвой ярости недвижимости, особенно в Рио-де- Неистовый рост обеспечивает появление деревень и фавел, где не найдена питьевая вода и, тем более, сточные воды. Рио-де- и Сан-Паулу, два крупнейших бразильских города, имеют серьезный дефицит сети очистки 
сточных вод и, несмотря на наличие международных кредитов, не в состоянии уменьшить высокий уровень загрязнения залива Гуанабара и реки Тьете, это Изза недостаточной осведомленности населения и программы экологического образования, которая стимулирует изменения в поведении людей.

Крупнейшие города страны плохо распоряжаются своими водными ресурсами. В 1997 году Всемирный банк предложил 40 миллиардов долларов США для компаний, вслажая санитарию. Почти 100\% денег по-прежнему остаются нетронутыми, потому что бразильские компании не подпадают под минимальные технические требования для получения кредитов-подтверждение геолог Альдо Rebou'as, минеральных ресурсов исследовательской компании - это потому, что банк Определяет, что компании имеют максимум 20\% потери в водораспределительных сетях. Только в Сан-Паулу в 2001 году потери составили $30 \%$.

Ухудшение состояния окружающей среды является одним из наиболее важных аспектов процесса деградации, прямо или косвенно вызванного человеком. Регионы, которые ранее имели объемы водных ресурсов, сегодня начинают давать признаки дефицита, и объяснение отходов с чрезмерной эксплуатации, заиления рек и загрязнения источников. И все эти проблемы возникают почти всегда в результате взрыва промышленного сельского хозяйства, которое служит для того, чтобы прокормить миллионы жителей городов. Фактом является то, что урбанизация и безудержный рост городов значительно увеличивают потребление и злоупотребление водой.

\section{ЧТО ДЕЛАТЬ ПЕРЕД ЛИЦОМ ТАКИХ ОТХОДОВ?}

Дезагрязняя вода является не только технической проблемой, но и экономическим и социальным порядком, поскольку не хватает ресурсов для внедрения систем очистки жидких сточных вод с помощью имеющейся технологии. Известно, что государства смогли захватить ресурсы через международные банки и сделать первые шаги в пользу наших источников, таких как в Рио-Гранде-ду-Сул, с Пре-Гуаиба (государственная программа) и Гуаба 
Виве, в столице Порту-Алегри, как Ссылка на проблему водных ресурсов. Однако многое еще предстоит сделать, потому что вода необходима во всех аспектах жизни. Пресноводные ресурсы являются важным компонентом гидросфреры Земли и неотъемлемой частью всех наземных экосистем, а также ее широко распространенной нехваткой, постепенным разрушением и увеличением загрязнения водных источников во многих регионах мира Осведомленность о спросе и изменения в отношении к воде. И в то время как многие растрачивать и отходов, другие уже страдают от последствий нехватки воды. Неравенство в распределении и отходы являются двумя вескими причинами, которые частично объясняют, почему 1,4 миллиарда человек, что почти в пять раз превышает население Соединенных Штатов, не имеют доступа к питьевой воде, а вода является основным фрактором для здоровья. Известно также, что 60\% водных ресурсов находятся только в девяти странах, в том числе в Бразилии, но 80 стран, представляющих 40\% населения мира, страдают от нехватки воды. Однако это не означает, что Соединенные Штаты, Бразилия, Россия, южная Африка или Китай, считаюющиеся богатыми водой странами, не свободны от проблем нехватки воды.

Что касается отходов, в соответствии с Родольфо Ф. Алвес Пена, сельское хозяйство несет ответственность за поглощение в среднем по всему миру, 70\% водоснабжения, и этот показатель идет до 80 до 90\% в слаборазвитых странах. Питьевая вода теряется в среднем 50\% в утечках распределительных систем, и если ничего не будет сделано в смысле поведенческих изменений, в 2025 году будет более 4 миллиардов человек, которые не будут иметь доступ к этой очень ценной и необходимой для жизни.

Поэтому необходимо комплексно проанализировать вопрос неотхода воды в сельской местности, в котором несколько фракторов влияют на изменение привычки производителей, в случае правильного использования гидрических ресурсов, как рассуждает Оливейра (2008 год):

Решение и вариант наиболее эфффективного использования природных ресурсов в целом и водных ресурсов в частности должны 
быть комплексныи и связаны с инструментами управления на всех соответствующих уровнях. Только таким образом можно будет достичь такого уровня, который позволит обеспечить адекватность спроса и предложения с целью рационального использования такого ценного ресурса. (OLIVEIRA, 2008, p.3)

Это осознание должно происходить в различных областях общества, независимо от социального, культурного и интеллектуального положения отдельных лиц. Это потому, что сегодня, европейский гражданин потребляет 150 литров воды в день, в то время как индийский должен согласиться только на 25 литров в день. Американец потребляет 3000 литров воды в день.

Хорошо бы подчеркнуть, что отходы бумаги больше отягчают в срубленных деревьев, а также потребление воды, так как, чтобы произвести тонну девственного волокна, необходимо 44000 до 83000 литров воды. Необходимо поощрять использование переработанной бумаги, поскольку на каждую тонну используемой бумаги может производиться почти тонна новой бумаги (более эфффективное, чем соотношение 2-3,5 тонн деревьев для производства тонны девственной бумаги). Следует стимулировать процесс экологического просвещения.

Пресная вода, ограниченный ресурс, является весьма уязвимой и несколько видов использования, поэтому она должна управляться комплексно с эфффективными механизмами координации и осуществления. В планах его использования необходимо подчеркнуть защиту, сохранение и устойчивое и рациональное управление, основанное на потребностях и приоритетах каждой общины. Оценка водных ресурсов является практической основой для ее комплексного и устойчивого управления, а также сбалансированного изучения потребностей населения и окружающей среды.

По всем причинам, представленным здесь, необходимо иметь в виду, что вода является самым ценным товаром этого века, это, однако, не означает, что нужно превратить "источник жизни" в денежную систему, генератор стольких 
конфликтов, а объединить усилия в пользу сознательного потребления и сохранения этого жизненно важного ресурса для обеспечения качества жизни будущих поколений.

\section{ЗАКЛЮЧИТЕЛЬНЫЕ СООБРАЖЕНИЯ}

Устойчивое развитие - это взаимосвязь между системами экономики человека и окружающей средой. Действия мужчин должны быть в гармонии с окружающей средой, гарантируя поддержание и сохранение для поддержания разнообразия, сложности и фрункционирования экологической системы, которые поддерживают нас. И мышление устойчиво необходимо, потому что природные ресурсы конечны. Кроме того, качество ресурсов становится все более ухудшимым из-за роста численности населения и отсутствия государственной политики, направленной на их сохранение. Например, по оценкам, ежегодно из-за проблем, связанных с качеством воды, умирает около 12 миллионов человек.

Единственным способом, с помощью которого большинство стран могут лечить растущее загрязнение своих водных ресурсов, является осуществление комплексных стратегий управления, которые не только помогают очистить курсы Д и Вода, но и в первую очередь предотвращают загрязнение. До настоящего времени лишь очень немногие страны фрактически смогли на практике отрабатывать такие изменения. Вы должны быть начеку. Нам придется избегать отходов, нарушать процессы загрязнения и создавать новые способы контроля, захвата и распространения.

Он принимает культурные и этические меры. Ситуация, при которой мир проходит, является не более чем более сложный образ жизни, где то, что один хочет "должен иметь", тем самым вызывая ускорение заводов и отраслей промышленности, которые являются одними из крупнейших пользователей воды только потери в сельском хозяйстве и полиэфире использования Пластиковые. B TWENTIETH веке население выросло в три раза, в то время как потребление воды увеличилось на шесть. Даже мы, бразильцы, которые имеют 16\% всей воды в мире, страдают от рациона из-за плохого управления ресурсами и 
неадекватной инфраструктуры. Засушливые страны сталкиваются с более пугающими проблемами, такими как Ближний Восток, где есть области, где дефицит ограничивает социально-экономический рост.

Совместные меры по управлению земле- и водными ресурсами должны быть более частыми в целях повышения эффективности использования ирригационных вод, тем самым избегая эрозии почвы, наводнений, осаждения, засоления и вредного воздействия Пестициды и удобрения в организмах. Кроме того, ухудшение состояния окружающей среды породило возникновение экологических патологий, а такие болезни, как холера и денге, стали более сильно вызваны загрязнением воздуха, воды и почв, а также использованием токсичных и опасных веществ, таких как Пестициды и другие специальные средства по уходу. Как мы видели до сих пор, деградация происходит не только в окружающей среде, но и в человеческом, ценности которого утрачены, где потребности уже не являются основными, а скорее лишними, где неправильно это правильно. Именно здесь мы будем рассматривать экологическое образование в качестве приоритета для достижения целей устойчивого развития. Тбилисская конференция, состоявшаяся в 1977 году, посвященный экологическому образованию на международном уровне, делает то, что Е.А. является фрормированием сознания, основанного на новой этике, которая будет противостоять любой эксплуатации. Это то, что нужно человечеству, чтобы повернуть свои действия, свои инвестиции, свои отношения, свои ценности, осознать, что оно не только думает о себе, что оно сможет дать здоровое будущее своим поколениям.

Мы знаем, что человек является основным причиной так много дисбаланса. Человек нарушил так полностью природной среды, где он переехал, что он больше не знает своего места в этой системе, за исключением, конечно, как расстройство фактор. До сих пор наши попытки доминировать в среде состояли из простых ландшафтных реформ, проведенных неуклюжим и неотражать; В то время как другие виды человеческой деятельности дали вредные, непредвиденные и плохо понимаемые побочные эффекты. Все океаны были 
загрязнены людьми, атмосферой и даже отдаленными ледниковыми слоями. Большинство рек более или менее загрязнены, и многие из них, такие, как река Тьете и Тибр, были преобразованы в канализацию под открытым небом. Барби Nadeau, журналист Newsweek в 2002 году был в Риме и дает показания о Тибра "... Они плавают мертвой рыбы уничтожены, не известно, для чего. Вонь везде, маслянистый остаток делает угрей и мертвых Карпов Свечение "и заключает:"... Если река является символической линией жизни города, то Рим находится в довольно плохой ситуации. Дело не в том, чтобы доминировать в среде, но знать, если природа может быть сохранена с определенным видом порядка, и если цивилизация способна выжить преобразования, которые провоцирует в природе. Культурная эволюция постепенно привела нас к признанию того, что гуманизация планеты может увенчаться успехом только в том случае, если будут соблюдаться основополагающие экологические законы.

Пришло время начать думать об изменении привычек. Почувствовать, что мы формируем вместе единую цепь; Если вы нарушите связь, цепь не будет иметь больше смысла. Каждый нуждается в каждом. Индийские ученые, тысячи лет назад, уже сказал, что все содержится в части и, насколько вещи кажутся разнообразными и множественное число, на самом деле, они являются аспектами той же и только реальность. Вот предложение, которое будет опосредовано, всеми нами, так что мы можем понять динамику жизни и видеть, что нет меня и да, узлы. До сих пор природа использовалась бесплатно, и благодаря ей мы производим и живем. Однако в панораме роста населения мира она не признала свою долженую ценность.

Что касается орошения, ответственного за отходы и последующее обязательство пружин, чтобы свести к минимуму последствия их неадекватного использования, Rebou'as (2001) подчеркивает, что необходимо более эфффективное и рациональное планирование использования орошения и оптимизации используемого оборудования. Это также может снизить затраты на электроэнергию. 
Еще одной недавней практикой в Бразилии, которая набирает силу, является использование повторного использования воды для обеспечения потребности в орошении различных продовольственных культур. Геспанхол (2002) дополняет, что в ряде стран, в которых используется этот метод, производительность значительно возрастает, когда хорошо спланирована.

Любая форма эффрективного использования воды, направленная на минимизацию отходов в полевых условиях, напрямую зависит от планирования, разработанного производителем. Планирование необходимо для согласования различных видов использования воды, что позволяет различным производственным секторам, контролировать количество и качество гидрических ресурсов, повышать уровень общей эффрективности использования (ПАЗ и др., 2000).

Во-вторых (FURRIELA,2001) Первой серьезной проблемой, которая возникает не только для сельского производителя, но и для всего человечества является осознание того, что нет неисчерпаемого снабжения питьевой водой на планете. Следует поощрять некоторые меры для обеспечения водоснабжения в количестве и приемлемых стандартов. Сегодня основная задача заключается в снижении уровня деградации водных ресурсов с помощью таких мер, как сохранение, улучшение основных санитарных условий, сокращение использования пестицидов, более чистое промышленное производство и управление потреблением.

С каждым днем становится все более очевидным необходимость воспринимать воду как экономическое благо, в котором ее управление должно основываться на принципах экономической эффрективности, таким образом, чтобы удовлетворять спрос с точки зрения устойчивости.

Он также добавляет, что необходимо установить новый образ мышления и действий, принимая различные привычки, виды использования и обычаи, где общей целью является экономический рост, основанный на устойчивом потреблении воды, тем самым способствуя защите Источники еще сохранились 
и восстановление тех, кто уже пострадал, он указывает, что этого недостаточно, и необходимо сделать гораздо больше для достижения этой цели должны рассматривать воду в качестве социального и экологического приоритета, так как это необходимо Заботиться о бразильских водных ресурсах, так как растущая потребность в мировой воде даст стране возможность использовать свой рост и развитие, а также внести существенный вклад в жизнь и любую продуктивную деятельность.

\section{БИБЛИОГРАФИЧЕСКИЕ ССЫЛКИ}

AGENDA 21. The Earth Summit Strategy to save our Planet. Ed. Daniel Sitarz, Earthpress, 321p. Boulder Colorado, 1994.

AGÊNCIA NACIONAL DAS ÁGUAS. Disponível em: <www.ana.gov.br> Acesso em: $20 / 07 / 2019$

Baía de todas as águas - Preservação e Gerenciamento Ambiental na Bacia Hidrográfica do Guaíba - Pró-Guaíba, RS/1998.

EBC. Disponível em: <www.ebc.com.br/.../mais-de-75-das-florestas-primarias-domundo-nao-existem-mais >Acesso em:19/07/2019

FURRIELA, R. B. EDUCAÇÃO PARA O CONSUMO SUSTENTÁVEL. Ciclo de Palestras sobre Meio Ambiente - Programa Conheça a Educação do Cibec/InepMEC/SEF/COEA, 2001.

HESPANHOL, I. Potencial de Reuso da Água No Brasil, Agricultura, Industria, Municípios, Recarga de Aquíferos. RBRH- Revista Brasileira Dos Recursos Hídricos. Vol. 7 n. 4, 2002

JUSBRASIL. Disponível em: <https://www.jusbrasil.com.br/topicos/10603350/artigo90-do-decreto-n-24643-de-10-de-julho-de-1934> Acesso em 20/07/2019 
MUNDO

DA

EDUCAÇÃO.

Disponível

em:

$<$ https://mundoeducacao.bol.uol.com.br/geografia/consumo-agua-no-mundo.htm> Acesso em 12 de setembro de 2018.

OLIVEIRA, E. C. A Gestão Dos Recursos Hídricos Sob a Perspectiva da Descentralização. ANAP BRASIL - REVISTA CIENTÍFICA, ano 1 nº 1, 2008.

PORTAL FMU. Disponível em: <https://portal.fmu.br/reciclagem-no-brasil-panoramaatual-e-desafios-para-o-futuro/> Acesso em: 20/07/2019

PUC RS. Disponível em: $<$ www.pucrs.br/edipucrs/online/planetaagua/planetaagua.pdf> Acesso em: 20/07/2019

REVISTA EDUCAÇÃO AMBIENTAL EM AÇÃO. Disponível em: <http://www.revistaea.org/artigo.php?idartigo=1271> Acesso em: 17/07/2019

REBOUÇAS, A. C. Água e desenvolvimento rural. ESTUDOS AVANÇADOS, 2001.

REBOUÇAS, A.C. Água no Brasil: Abundância, Desperdício e Escassez.BAHIASalvador, v. 13, n. ESPECIAL, p. 341-345, 2003 ANÁLISE \& DADOS

SILVA,J. S. Água e Agricultura Irrigada. Palestra-Seminário Agricultura Irrigada Com Desenvolvimento Sustentável-Universidade Federal De Uberaba-Em 24-09-2009. Disponível em: http:www.irrigacao.org.brdocdownloadAgua\%20Agricultura\%20Irrigada_JoseSilverio. pdf.. Acessado em: 20/07/2019

TUCCI, C. E. M. Gestão da água no Brasil. Brasília: UNESCO, 2001. 156p.(1. Hidrologia - Brasil II. Hespanhol, Ivanildo III. Cordeiro Netto,

VICTORINO, C. J. A. Planeta água morrendo de sede: uma visão analítica na metodologia do uso e abuso dos recursos hídricos. Porto Alegre: EDIPUCRS, 2007.231 p. (1. Água - Uso. 2. Água - Qualidade. 3. Recursos). 
Представлено: Июнь, 2019.

Утверждено: август 2019 года. 